DE DE GRUYTER OPEN
Journal of Intercultural Management

Vol. 6, No. 4, December 2014, pp. 159-167

DOI 10.2478/joim-2014-0042

Rocío del Carmen Payares Flores*

Universidad de Occidente

\author{
Aída Alvarado Borrego* \\ Universidad de Occidente
}

\title{
The organizational culture in the fishing cooperative society of Sinaloa
}

\begin{abstract}
Organizational culture is a phenomenon that identifies members of the fishing cooperative "Peninsula Lucenilla" as part of the values, symbols, ideology, customs, language, among others. The importance of organizational culture identifies those who belong to a union, because they are hard-working, talkative, enthusiastic, responsible, and ethical people.

Research aimed to analyze the organizational culture in the fishing cooperative of Sinaloa. The study was conducted with a qualitative approach; through a study case. Data collection was carried out from members of the cooperative, as well as a couple of interviews to the president.

The main results of the study indicate that organizational culture in the fishing cooperative of Sinaloa is manifested in all of the activities that fishermen performed when the ban is lifted, how shrimp and other fishes are delivered.

Based on that, we conclude that organizational culture identifies those who belong to an organization that represents the lifestyle of fishermen, for example; as in the case of a fishing cooperative.
\end{abstract}

Key words: organizational culture, fishing cooperative

\section{Introducción}

Organizational culture decides the identity that people have in an organization. It is a topic that many authors have defined coincide with the idea of talking about

\footnotetext{
*rpayares@yahoo.com; aidaalvaradoborrego@prodigy.net.mx
} 
the customs, ideology, beliefs, artifacts and activities that occur within organizations and determine the behavior of employees, identifying them. Moreover, as Daft (2007: 361) argues, organizational culture is perceived but the unwritten part of the organization.

The objective of this research is to analyze the organizational culture of the fishing cooperative of Sinaloa. Specifically, the fishing cooperative "Peninsula Lucenilla" located in the Bay of Altata in Navolato, Sinaloa, was investigated was a study in depth about the values, beliefs, language and ideology of fishermen associated in a particular cooperative with a committee that represents it.

The cooperative is an association formed by people called "partners", gather in assemblies to make arrangements and help its members. We can identify different cooperatives: the associated work, pharmaceutical, agricultural, savings and credit services, fisheries, among others.

Fishing cooperatives in Mexico are governed by the General Law of Cooperative Societies, published in the Official Gazette on August 13, 1994 and its last revision was published DOF 13-08-2009. This Act establishes the directions to be followed by these organizations that are part of cooperatives and are based on a series of articles that serve to shape and can be set up to enforce their rights and obligations are regulated.

Currently Sinaloa cooperatives have taken hold, contrary to what people might think. The objectives of cooperative work are crucial for fishermen take this form of organization as an alternative to gain access to the products of the oceans, in addition to market. But even more important are the support given by the government, which individually could not achieve.

Although not identified extreme poverty in fishing cooperatives located in Altata, in the town of Navolato, Sinaloa, fishermen seeking other activities, such as tourism, which helps them obtain other employment.

\section{Methods}

The manner in which this research was addressed was through a qualitative methodology, this approach according Bonilla and Rodriguez (2000) cited in Bernal (2010), aims to develop more specific and not to generalize things, but to make this decision first made an exploratory study to Rojas (2011), "exploratory study aims to gather information to recognize" data to determine how to address the analysis. Una vez que se hizo el estudio exploratorio acudiendo al lugar geográfico del sujeto de estudio, se fue conociendo poco a poco la forma de organización de la sociedad cooperativa que permitió el acceso.

A survey of twenty-five of the fifty-five of the members of the cooperative, for convenience and for the results that were obtained are made. The survey was conducted in June 2013 in the homes of fishermen and in the building of "La Lonja" where the cooperative is located. 
The total of the questions were twenty, and multiple choice questions were, closed and open. Plus a couple of interviews were chairman and 6 members more seniority also made observation, analysis of documents and photographs of the fishermen were taken when they were administered the surveys, and when they were doing their job, in their houses in the village, also the building where the cooperative is located, to gear, to craft, and fishing products.

\section{Current knowledge on Organizational Culture}

Every organization has a culture that distinguishes and identifies and directs it towards certain types of actions and ways of working; while that culture governs perceptions and the image that people form of it (Hernandez Gallarzo, Espinoza, 2011: 92).

The word culture comes from the Latin cults ("cultivated") and -ura ("action", "result of an action"), meaning "cultivation", "agriculture" or "instruction." In a similar sense, this term belongs to the family cotorce (cultivar, dwell) and colows (settler, farmer, peasant). Over time, the word acquired culture different meanings. One indicates a mixture of traits and spiritual and emotional features that characterize a society or social group in a given period. Also encompasses lifestyles, ceremonies, art, inventions, technology, value systems, fundamental rights of human beings, traditions and beliefs. This concept is used for a long time to refer to a product of the interaction activity of society. However, since 1980, Tom Peters and Robert Waterman, McKinsey consultants, anthropological and psychosocial adapted this concept to organizations (Hernández et al. 2011:91).

Table 1. Definition of organizational culture

\begin{tabular}{|l|l|}
\hline AUTHOR & CONTRIBUTION \\
\hline $\begin{array}{l}\text { Richard L. Daft } \\
(2001: 361)\end{array}$ & $\begin{array}{l}\text { Define what culture ,is the set of values, norms, guiding and shared } \\
\text { by members of an organization, same as new members are taught } \\
\text { understandings beliefs.” }\end{array}$ \\
\hline $\begin{array}{l}\text { Gibson, Ivancevich, Don- } \\
\text { nelly (2001:67) }\end{array}$ & $\begin{array}{l}\text { "A national culture is a set of values, beliefs, and shared by a majority } \\
\text { of the inhabitants of a country standards. These become incorpo- } \\
\text { rated in the laws and regulations of the society, as well as generally } \\
\text { accepted standards of the country's social system. “ }\end{array}$ \\
\hline $\begin{array}{l}\text { Idalbertho Chiavenato } \\
(2004: 120)\end{array}$ & $\begin{array}{l}\text { Define culture: „Every society or nation has a culture that influ- } \\
\text { ences the behavior of individuals and organizations. Culture includes } \\
\text { shared, policy work, traditions and objectives that are passed from } \\
\text { one generation to another ,values. }\end{array}$ \\
\hline
\end{tabular}




\begin{tabular}{|l|l|}
\hline $\begin{array}{l}\text { Ronald B. Adler, Jeanne } \\
\text { Marquardt Elmhorst }\end{array}$ & $\begin{array}{l}\text { Cultural diversity and communication ,, is a fact in the world of work } \\
\text { today. Consider the following statistics. In the 1970s it was estimated } \\
\text { that eight of every American was black or Hispanic or Asian origin; } \\
\text { for the 1990s things had changed, so that one in four belonged to } \\
\text { one of these groups. “ }\end{array}$ \\
\hline $\begin{array}{l}\text { Carlos Fernández Col- } \\
\text { lado, Laura Galguera } \\
\text { García (2008:172) }\end{array}$ & $\begin{array}{l}\text { Define: ,Since it was the West know the culture of different nations } \\
\text { to communicate and, most importantly, to negotiate with them.” }\end{array}$ \\
\hline $\begin{array}{l}\text { Angelo Kinicki, Robert } \\
\text { Kreitner (2008:30) }\end{array}$ & $\begin{array}{l}\text { Define: „Organizational culture is the set of shared and implicit as- } \\
\text { sumptions that are taken for granted, in a group, which determines } \\
\text { how the group perceives its various environments, thinks about and } \\
\text { reacts to it themselves.” }\end{array}$ \\
\hline $\begin{array}{l}\text { Stephen Robins (2011:595) } \\
\text { Defines culture as ,common perception held by members of the } \\
\text { organization, system of shared meaning.” }\end{array}$ \\
$\begin{array}{l}\text { Jorge A. Hernández, } \\
\text { J. Espinoza (2011:92) }\end{array}$ & $\begin{array}{l}\text { Define organizational culture is a set of behaviors that are shared by } \\
\text { members of an organization. }\end{array}$ \\
\hline
\end{tabular}

Source: Prepared with information from authors.

"Culture provides members with a sense of organizational identity and generates in them a commitment to the beliefs and values that are larger than themselves" (Daft, 2007: 361).

According to Daft (2007: 362), culture serves two critical functions of organizations: 1) integrate members so they know how to relate to each other, and 2) help the organization to adapt to the environment. Internal integration means that members develop a collective identity and know how to work together effectively. The external adaptation refers to the way in which organizations achieve their goals and treat external. Culture helps guide the daily activities of workers to achieve certain goals.

Organizational culture is part of the working life of all. The manifestations of culture in organizations include formal practices (eg, wage levels, hierarchy, structure, job descriptions and other written policies); informal practices (eg performance standards), employees of the organization have stories to explain "how things are done around here," rituals (such as Christmas parties and retirement dinners), humor (jokes about work and co-workers); jargon (special language), and physical arrangements (including the interior decoration, the dress and organizational).

Cooperative societies emerge into the world as an alternative to work together by those who compose it and most of the time, to fill the void left by the big companies. In Mexico, the cooperative societies work differently from other firms is because their partners are the owners and managers of management, production and marketing of goods produced. In the case of fisheries cooperatives, partners affect them directly gains or losses obtained from the activities carried out; are those who know the art of fishing, which is the right time to do it, know the situation in which the product is, they warn that climate changes affecting seafood. 
The fishing cooperatives are created due to the need for fishermen to organize and profit, seeking to improve the areas where they arise; economically disadvantaged areas, often marginalized; and aim to find the livelihoods of families living in these areas.

Culture plays an important role in their activities fishermen, the president of the cooperative should consider each of the cultural events additionally perform a ritual when "start" fishing, obtaining the raw material for the Arts this activity, meeting the needs of fishermen, as well as be aware of what they catch.

\section{History of the fishing cooperative "Lucenilla"}

The Fisheries Cooperative Riparian Lucenilla Peninsula began in known address in the Port of Altata with registration No. 8033-P. It is located in the Bay of Altata municipality of Navolato, Sinaloa; one of 18 in the state; by its proximity to Culiacan, the state capital, receives a large influx of visitors, attracted by the gastronomy, the main attraction of this place. Lucenilla belongs to the Federation of Sea Waters of Ensenada Bay and Altata Pavilion, comprising twelve cooperatives.

The cooperative was founded in 1982, the first committee was led by Jorge Luis Valenzuela. Arnoldo Valenzuela Quinonez as secretary, Humberto Contreras and Gerardo Hernandez Leyva Leobardo.

Fishermen Bay Altata have several benefits by becoming as cooperatives, as being organized, seeking greater government support; so members have the opportunity to place your product in a safe manner, to commercialize and profit thereby. The number of members varies between 55 and 70 use the technique of Suripera. ${ }^{1}$

The cooperative "Lucenilla" has permission to fish shrimp, shark, flake and clam. And it is one of the three most successful cooperatives in Altata, Sinaloa, Mexico. Its chairman until July 2014, Mr. Avelardo Quinonez has participated in various events related to fishermen nationwide, and also worked a few months ago to train fishermen in the country of Nicaragua.

Altata is located at coordinates: longitude and latitude 243808 1075557, an average height of one meter above sea level. Its population to date is 2001 people, of which 1022 are male and 979 female. The economically active population is 776 people (INEGI, 2012). In Navolato, predominantly warm dry climate, with summer rains and low throughout the year. The average annual temperature is $24^{\circ} \mathrm{C}$, where the annual rainfall ranges 433.5 to 511.6 in millimeters, (Enciclopedia de los Municipios y Delegaciones de México, 2013).

\footnotetext{
The cast net „Suripera” or „Dragona” is an active network or removable during operation, consisting of a semi-conical skirt with leads in its widest part, which graze the bottom (National Fisheries Institute 2000). The narrowest part of the skirt contains funnels and handbags, wherein, gets caught shrimp to climb the skirt. The network operates according to water currents and / or wind (Inapesca 2013, disponible en: http://www.wwf.org.mx. 20 de Julio de 2013)
} 
Figure 1 Map of Sinaloa

Figure 2 Map of Navolato

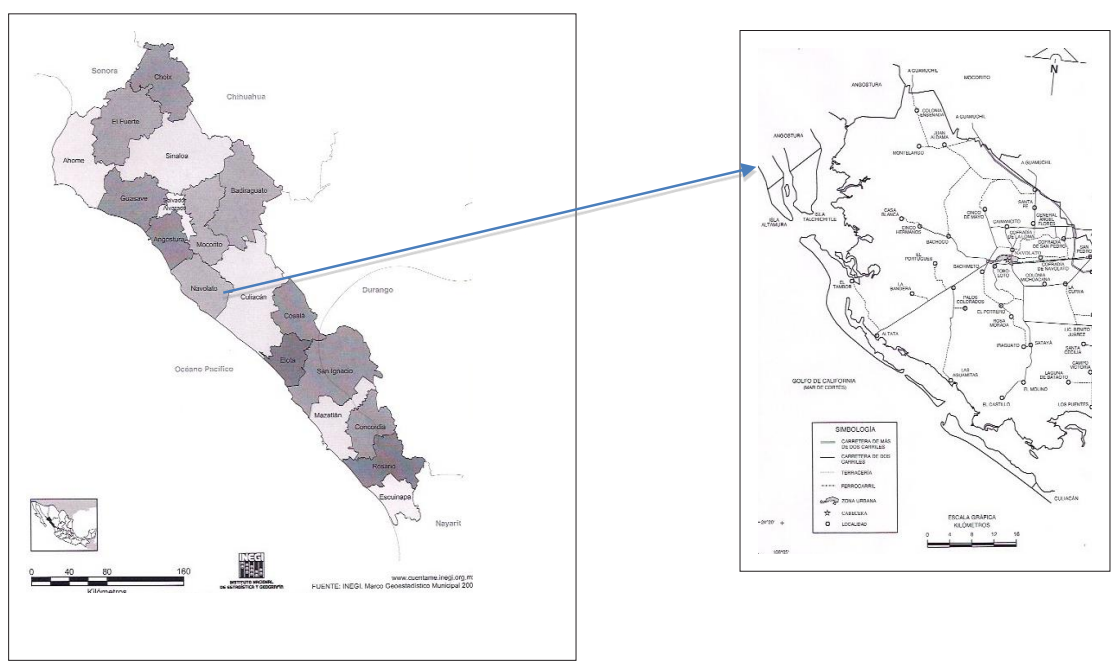

Sourse: INEGI (2013)

The members of the cooperative, in addition to fishing, manage it and develop management to benefit from successive governments to take advantage of programs that support fishermen. Also, display a culture of community development and environmental stewardship, market and sell products extracted from the sea a way that benefits them and give them to the family support, but also are an important part of the culture in which citizens living in the village of Altata therefore think nothing in fishing as an activity that gives them to eat, but to survive in an environment of social coexistence.

The cooperative has 34 fishing boats with motors, of which 20 are green, plus gear: seines, cast nets suriperas.

The facilities of the cooperative, which currently stands at "La Lonja", consisting of an office that is shared with another cooperative, a cold room to store the product, with a capacity of three by three meters. It also has a roof five by sixteen feet, covering the nine stainless steel tables with six banks, which are used for the classification of shrimp. Also with a "palapa", which will in the near future to allow fishermen to offer their products directly to customers; currently sell some products and only season. Another part that is located on the premises of the cooperative, are the fuel tanks with a capacity of 10,000, and 7,000 liters, respectively where the fuel supply. 


\section{Results}

Culture in an organization can be manifested in different ways. It is said that organizations work through rituals; each of the activities performed by employees becomes a ritual, for example, a fisherman gets up very early, meets each of the items that take up fishing and performs every time you go fishing, meticulously and rigorous, each of the actions. Another manifestation, are myths; In most organizations there are beliefs, which in many cases are not real.

The legends arise Altata Bay; stories, some of the times fictional plagued counted. Another way you can identify the culture is language, as each organization has his own. Fishermen have a very colloquial language, with words considered grotesque or aggressive. The artifacts and objects are essential, have a terminology that only they identify. Altata fishermen from months before they begin to build networks called "monkeys" or also known as "hammocks"; have a whole methodology to develop them, and regularly do more experienced fishermen.

With respect to culture, it is identified that members of the fishing cooperative "Lucenilla" perform a series of rituals as they go fishing they believe in a supreme being who blesses when you start fishing, celebrate the day of the ocean, the day father and inns.

The aspect that comes to light whenever they ask question about problems they are fishermen, closed season is the shrimp, main product have fished for years, and, as time passes, are less likely to get, as they face a series of problems to go fishing.

Moreover, fishermen agree to continue to work cooperatively for the marketability of its products, in addition to preventing poaching and receive the support provided to them by government agencies, although insufficient, to date gives some security to continue their activity.

In this research, the fishing cooperative organization described from a cultural perspective, values are Identified, beliefs, ideology, customs, language, symbols, the founders.

Fishermen have values such as responsibility, hard work, early, respect the time of closure; believe in a higher being, but also afraid to legendary beings who for years have thought exist: one example, when they say a fisherman to go fishing for the first time "has to suck anchor" to be at sea ; identifies ideology as they are convinced that it is, for example, when not go fishing, based on the meaning of the moons, "when the moon is full there will be good fishing"; Fishermen gather in the house of a partner, or go to "La Lonja" for the day, although they are not fishing.

They also meet in the evenings to play volleyball, play tennis games made by themselves ground even do barefoot; fishermen have slang, used some words that only they understand, but also have no verbal language that makes communicating at a distance when they are fishing; symbols used by fishermen, ranging from what a shrimp on the letterhead printed using the cooperative, to the knowledge of the 
lunar images. The founders of the cooperative partners, are of great importance, because at present remain a fundamental part of the organization of society.

Today, the fishing cooperatives have been transformed; to what the founders of these organizations was a simple task of great abundance, today becomes complicated and uncertain for several reasons that were identified in the research findings. On one hand, there are large organizations engaged in fishing, and secondly, the rapid population growth and the lack of care for the environment, has resulted in a time shorter fishing, marine products and in particular shrimp, very little time is left on the shore of the bay, and when the harvest begins, most of the crustaceans migrate to sea.

The abundance of seafood that was twenty years ago, today it is no longer, so the fishermen, together with government authorities concerned with this situation, have had to make steps to resolve it.

\section{Concluding remarks}

With regard to the findings in the diagnosis of results, analysis of documents, is an organization that has a culture of identity that makes it unique, and that during all the time that has existed, it has made a reputation, so that those who belong to "Lucenilla" fishermen are responsible and ethical employees, as opposed to the other two cooperatives in the Bay Altata; in this cooperative poaching does not occur, they have very clear that it is unethical and will receive greater support if they work in a coordinated manner; there are upward and downward communication. All this could be identified in the answers they gave fishers when asked about the subject of each of the analysis categories.

\section{Bibliography}

Adler y Marquardt. (2005). Comunicación organizacional. Principios y prácticas para negocios y profesionales. México: Editorial Mc Graw Hill.

Bernal, C. A. (2010). Metodología de la investigación. Editorial Pearson.

Chiavenato, I. (2004). Comportamiento Organizacional. México: Mc. Graw Hill.

Daft, L. R. (2007) Teoría y diseño organizacional. México: Editorial Thomson.

Diccionario Enciclopédico de los Municipios y Delegaciones de México (2013). Tomado de: www.elocal.gob.mx.

Fernández C. C. y Galguera L. (2008). La comunicación bumana en el mundo contemporáneo. México: Mc. Graw Hill.

Gibson, I. y Donnelly, Jr. (2001). Las organizaciones. México: Editorial Mc Graw Hill.

Hernández J.A., Gallardo M., Espinoza J. De J. (2011). Desarrollo organizacional, enfoque latinoamericano. Editorial Pearson. México.

Inapesca 2013. www.wwf.org.mx 
Instituto Nacional de Estadística Geografía e Informática INEGI (2013).

Kinicki y Kreitner. (2008). Comportamiento Organizacional. Conceptos, problemas y prácticas. México: Mc Graw Hill.

Ley General de Sociedades Cooperativas. (2011). México: ISEF.

Rojas S. R. (2011). Guía para realizar investigaciones sociales. Plaza y Valdés Editores. 